\title{
MENYOAL URGENSI DAN PROSEDUR PEMBENTUKAN REVISI UNDANG-UNDANG KOMISI PEMBERANTASAN KORUPSI
}

\author{
Madaskolay Viktoris Dahoklory \\ Program Studi Magister Ilmu Hukum, Fakultas Hukum Universitas Diponegoro \\ e-mail: viktorisdahoklory@gmail.com \\ Muh Isra Bil Ali \\ Program Studi Magister Ilmu Hukum, Fakultas Hukum Universitas Diponegoro \\ e-mail: israbi194@gmail.com
}

\begin{abstract}
ABSTRAK
Revisi Undang-Undang Komisi Pemberantasan Korupsi yang selanjutnya disingkat revisi UU KPK yang menjadi usul inisiatif DPR, menimbulkan pro kontra di tengah masyarakat, sebab sebagain besar masyarakat menganggap undang-undang KPK saat ini tidak perlu direvisi, ada pula yang mengatakan bahwa proses pembentukan revisi undang-undang KPK ini tidak ditempuh melalui prosedur dan tahapantahapan sebagaimana telah diatur dalam undang-undang. Penelitian ini akan membahas permasalahan mengenai urgensi dilakukannya revisi undang-undang KPK, dan prosedur pembentukan UU yang baik dan benar, serta penerapannya dalam pembentukan revisi undang-undang KPK. Metode yang digunakan dalam penelitian ini adalah metode yuridis normatif dengan menggunakan perundang-undangan dalam menganalisis permasalahan yang menjadi fokus penelitian. Hasil Penelitian menyimpulkan bahwa urgensi dilakukannya revisi UU KPK adalah karena UU No. 30 Tahun 2002 sudah tidak sesuai dengan perkembangan zaman dinamika hukum serta sistem ketatanegaraan Republik Indonesia, dan Proses revisi UU KPK ternyata tidak melalui prosedur-prosedur sebagaimana telah diatur dalam "Undang-Undang No. 12 Tahun 2011 tentang Pembentukan Peraturan Perundang-Undangan” sehingga mengakibatkan kecacatan dari segi prosedur pembentukan peraturan perundang-undangan yang baik dan benar.
\end{abstract}

Kata Kunci: Urgensi; Revisi; Undang-Undang; KPK

\section{ABSTRACT}

Revision of the Corruption Eradication Commission Law, hereinafter abbreviated as revision of the KPK Law which became a proposal of the DPR's initiative, raises pros and cons in the community, because most of the community considers the old KPK law does not need to be revised, there are also those who say that the process of forming the revision of the law This KPK law was not pursued through procedures and stages as regulated in the Act. This research will discuss issues regarding the urgency of revising the KPK law, and the procedure for establishing a good and correct law, and its application in forming the revision of the KPK law. The method used in this study is a normative juridical method by using legislation in analyzing the problems that are the focus of research. The results of the study concluded that the urgency of the KPK Law revision was due to Law No. 30 of 2002, is not in accordance with the development of the era of legal dynamics and the constitutional system of the Republic of Indonesia, and the revision process of the KPK Law apparently did not go through the procedures as regulated in "Law No. 12 of 2011 concerning Formation of Laws and Regulations" resulting in disability in terms of procedures for the formation of legislation that is good and right.

Keywords: Urgency; Revision; Law; KPK 


\section{PENDAHULUAN}

Keseriusan Indonesia dalam memberantas korupsi terlihat dari beberapa kebijakan nasional, yang dituangkan dalam beberapa regulasi seperti; "Undang-Undang Nomor 28 Tahun 1999 tentang Penyelenggara Negara yang Bersih dan Bebas Korupsi, Kolusi, dan Nepotisme; Undang-Undang Nomor 31 Tahun 1999 tentang Pemberantasan Tindak Pidana Korupsi sebagaimana telah diubah dengan Undang-Undang Nomor 20 Tahun 2001 tentang Perubahan atas Undang-Undang Nomor 31 Tahun 1999 tentang Pemberantasan Tindak Pidana Korupsi”.

Berdasarkan bunyi "Pasal 43 Undang-Undang Nomor 31 Tahun 1999 tentang Pemberantasan Tindak Pidana Korupsi sebagaimana telah diubah dengan Undang-Undang Nomor 20 Tahun 2001", mengamanatkan agar paling lambat 2 (dua) tahun dibentuk suatu Komisi Pemberantasan Tindak Pidana Korupsi (yang selanjutnya disebut KPK).

KPK bertugas dan berwenang untuk "berkoordinasi dan melakukan supervisi, termasuk melakukan penyelidikan, penyidikan, dan penuntutan". ${ }^{1}$ Setelah adanya gerakan reformasi pada tahun 1998, muncul semangat dan kesadaran bahwa korupsi, kolusi, dan nepotisme (KKN) adalah musuh bersama bangsa Indonesia. Atas semangat dan kesadaran inilah beberapa badan dibentuk, demi mencegah dan melawan KKN di Indonesia. Beberapa di antaranya adalah "Komisi Pengawas Kekayaan Penyelenggara Negara (KPKPN) dan Tim Gabungan Pemberantasan Tindak Pidana Korupsi (TGPTPK)". Tugasnya yaitu melakukan pemeriksaan dan pengawasan harta kekayaan pejabat negara. Sedangkan TGPTPK bertugas melakukan pemburuan koruptor di luar negeri, dari sinilah KPK dibentuk. Dibentuknya KPK hampir sama dengan komisi serupa di negara-negara lain, seperti Hongkong. Negara Hongkong memiliki lembaga pemberantasan korupsi yang bernama "Independent Commission Against Corruption (ICAC)”. Saat ini ICAC berhasil mengurangi tingkat korupsi di Hongkong. ${ }^{2} \mathrm{KPK}$ dibentuk dikarenakan lembaga-lembaga utama penegakkan hukum seperti lembaga kepolisian dan

${ }^{1}$ F. Fazzan. (2015). "Korupsi di Indonesia dalam Perspektif Hukum Pidana Islam.” Jurnal Ilmiah Islam Futura. 14(2), 146165. DOI: http://dx.doi.org/10.22373/jiif.v14i2.327

${ }^{2}$ Naskah Akademik UU KPK, h. 10-11. kejaksaan gagal dalam bekerja untuk memberantas korupsi secara efektif. Kehadiran KPK sebagai anak kandung reformasi menunjukkan adanya keseriusan Negara dalam melawan praktik korupsi, kolusi, dan nepotisme. ${ }^{3}$ Pasal 3 UU KPK menegaskan bahwa "KPK merupakan lembaga independen dalam melaksanakan tugas dan wewenangnya. Korupsi merupakan perilaku akibat kehancuran moral dan etika seseorang, sengaja dilakukan untuk mendapatkan keuntungan pribadi atau golongannya (kelompok tertentu) yang menimbulkan kerugian keuangan negara. ${ }^{4}$

Dibentuknya KPK dikarenakan bangsa Indonesia sadar bahwa korupsi merupakan musuh bersama yang mengancam kelangsungan hidup seluruh masyarakat Indonesia. ${ }^{5}$ Korupsi saat ini telah sampai pada tataran yang mengkhawatirkan sebab prilaku koruptif telah masuk ke berbagai aspek kehidupan bermasyarakat, berbangsa, dan bernegara. Data menunjukan adanya peningkatan perkara korupsi dari tahun ke tahunnya. Peningkatan jumlah perkara korupsi terus meningkat dari tahun ke tahun bisa terlihat dari data berikut: Tabel 1:

Jumlah Perkara Berkekuatan Hukum Tetap Tahun 2015-20196

\begin{tabular}{cccccc}
\hline Tahun & 2015 & 2016 & 2017 & 2018 & 2019 \\
\hline $\begin{array}{l}\text { Jumlah } \\
\text { Perkara }\end{array}$ & 37 & 70 & 84 & 104 & 128 \\
\hline
\end{tabular}

Berdasarkan tabel tersebut menunjukan dari tahun 2015 hingga tahun 2019, terjadi peningkatan jumlah perkara korupsi di Indonesia. Meningkatnya jumlah perkara korupsi di Indonesia yang seakan tak terkendali, akan berdampak buruk dalam kehidupan bernegara, khususnya terhadap kehidupan perekonomian nasional. Korupsi semakin meluas dan

\footnotetext{
${ }^{3}$ Deni Styawati. (2008). KPK Pemburu Koruptor (Cet 1). Yogyakarta: Pustakan Timur, h. 1.

${ }^{4}$ Novian Ardynata Setya Pradana, Arif Subekti, dan Cahyo Harjo Prakoso. (2019). ”Kewenangan Lembaga Hukum Dalam Menentukan Besaran Kerugian dan Pengembalian Keuangan Negara Hasil Tindak Pidana Korupsi”. Jurnal Perspektif, 24(3), 137-146, doi. http://dx.doi.org/10.30742/perspektif.v24i3.719

${ }^{5}$ Rimawan Pradiptyo, Teguh Dartanto, Sonny Priyarsono, Maman Setiawan, Gumilang Aryo, Sahadewo, Putu Sanjiwacika Wibisana. (2019). "Naskah Akademik, Menghapus Pulau Berintegritas Atau Membangun Kepulauan Berintegritas? Rekomendari Ekonom Terhadap Pelemahan Penindakan dan Pencegahan Korupsi”. Departemen Ilmu Ekonomi (UI, IPB, UNPAD, UGM), h. 43.

${ }^{6}$ Website Komisi Pemberantasan Korupsi, https://www. kpk.go.id/id/statistik/penindakan, diakses pada 27 Maret 2020.
} 
tersistematis adalah bentuk pelanggaran terhadap hak asasi manusia, khusus hak sosial dan hak ekonomi masyarakat, sehingga korupsi disebut sebagai extra ordinary crime. ${ }^{7}$ Hal ini membawa konsekuensi logis bahwa korupsi harus diberantas dengan caracara yang "luar biasa", dengan menghadirkan suatu lembaga yang luar biasa, lembaga itu adalah KPK. Kalau KPK itu kemudian tidak luar biasa maka tidak ada gunanya, sebab pada mulanya tugas pemberantasan korupsi ini ada di tangan Kepolisian dan Kejaksaan, namun karena dua lembaga ini tidak bekerja dengan efektif dan efisien dalam pemberantasan korupsi, maka dibentuklah KPK. ${ }^{8}$ "Sehingga apabila KPK menjadi lembaga yang biasa saja disinilah ia kehilanyan ruhnya".

Namun dalam pelaksanaan tugas dan wewenangnya, KPK mengalami banyak hambatan, hal ini menjadikan "pemberantasan korupsi di Indonesia bekerja secara pasang surut di tengah himpitan dominasi kepentingan politik dan kekuasaan". ${ }^{9} \mathrm{Hal}$ ini ditandai dengan adanya upayaupaya yang mencoba untuk mengintervensi tugas, wewenang serta kelembagaan KPK. Antara lain Pembentukan Panitia Khusus (Pansus) Angket terhadap KPK yang dilakukan oleh DPR, ${ }^{10}$ hingga berujung pada revisi "UU KPK" telah menjadi "Rancangan Undang-Undang" usul inisiatif DPR dalam sidang paripurna Kamis, 5 September 2019 bertekad untuk menyelesaikan pembahasan revisi "UU KPK" sebelum periode jabatan, yaitu tahun 2014-2019 berakhir pada 30 September 2019 silam. Usul Revisi "UU KPK" yang sebelumnya tidak masuk program legislasi nasional, menuai pro-kontra di masyarakat Indonesia. Salah satu pro kontra yang sangat menyita perhatian masyarakat yaitu adanya dewan pengawas dalam kelembagaan KPK. Yokotani

${ }^{7}$ Ibu Srinita. (2016). "Strategi Menihilkan Korupsi di Sektor Pendidikan dan Kesehatan". Jurnal Kajian Politik dan Masalah Pembangunan. 12(2), 1891-1902.

${ }^{8}$ Totok Sugiarto. (2013). "Peranan Komisi Pemberantasan Korupsi (KPK) dalam Pemberantasan Tindak Pidana Korupsi di Indonesia”. Jurnal Cakrawala Hukum. 18(1), 188-196.

9 KASUM. (2010). "Korupsi adalah Kejahatan HAM". Makalah disampaikan pada acara Munir Memorial Lecture (MML) IV Samanta Krida Conventional Hall Universitas Brawijaya, 29 September 2010, h. 2.

${ }^{10}$ Hussein Abri, Editor: Ninis Chairunnisa. (Jumat, 2 Februari 2018). "Berikut Ini 10 Rekomendasi Pansus Hak Angket untuk KPK”, (https://nasional.tempo.co/read/1056595/berikutini-10-rekomendasi-pansus-hak-angket-untuk-kpk, diakses pada 29 Maret 2020. dan Ndaru Satrio, dalam tulisannya yang berjudul "Mekanisme Seleksi Dewan Pengawas Komisi Pemberantasan Korupsi dalam Perspektif Cita Hukum Pancasila" menyatakan bahwa "keberadaan Presiden dan DPR sebagai lembaga negara yang turut membentuk pimpinan dan anggotanya sangat tidak tepat. Hal ini dikarenakan konflik kepentingan yang besar kemungkinan akan terjadi ketika dihubungkan dengan beberapa tugas dari KPK itu sendiri". ${ }^{11}$

Kritikan terhadap RUU revisi terhadap UU KPK, seakan angin lalu bagi Pemerintah, sebab pada tanggal 17 Oktober 2019, Undang-Undang KPK yang lama telah digantikan. Berlakunya UU KPK yang baru, menyisakan berbagai persoalan yang menarik untuk di bahas dan diketahui jawaban atas persoalan tersebut. Persoalan tersebut antara lain menanyakan urgensi dilakukannya revisi terhadap UU KPK, sebab masyarakat ada yang tidak setuju terhadap revisi tersebut. Persoalan lainnya adalah apakah prosedur pembentukan revisi UU KPK telah sesuai dengan prosedur yang sebagaimana diatur pada UndangUndang No. 12 Tahun 2011 tentang Pembentukan Peraturan Perundang-Undangan, sebagaimana telah perbaharui melalui Undang-Undang No. 15 Tahun 2019 atau belum? Persoalan inilah yang akan dibahas lebih lanjut dalam tulisan ini.

Penelitian serupa dengan penelitian ini telah dilakukan oleh "Dalinama Telaumbanua, dalam penelitiannya yang berjudul Restriktif Status Dewan Pengawas KPK, penelitian ini khusus membahas permasalahan mengenai status dewan pengawas KPK". ${ }^{12}$ Penelitian lain yang serupa juga dilakukan oleh "Edita Elda, dalam penelitiannya yang berjudul Arah Kebijakan Pemberantasan Tindak Pidana Korupsi di Indonesia: Kajian Pasca Perubahan Undang-Undang Komisi Pemberantasan Korupsi". ${ }^{13}$ Penelitian ini membahas mengenai arah kebijakan atau orientasi yang ingin dicapai oleh "UU KPK"

\footnotetext{
${ }^{11}$ Yokotani dan Ndaru Satrio. (2019). "Mekanisme Seleksi Dewan Pengawas Komisi Pemberantasan Korupsi Dalam Perspektif Cita Hukum Pancasila”. Jurnal Hukum Progresif. 13(2), 115-133. DOI: https://doi.org/10.33019/progresif. v13i2.1452.

${ }^{12}$ Dalinama Telaumbanua. (2020) "Restriktif Status Dewan Pengawas KPK". Jurnal Education and Development. 8(1), 258258.

${ }^{13}$ Edita Elda. (2019). “Arah Kebijakan Pemberantasan Tindak Pidana Korupsi di Indonesia:Kajian Pasca Perubahan Undang-Undang Komisi Pemberantasan Korupsi”. Lex LATA. 1(2), 153-170.
} 
yang baru. Berdasarkan perbandingan dengan penelitian serupa yang telah dilakukan, penelitian ini merupakan penelitian yang baru, karena berbeda dengan penelitian sebelumnya, perbedaan tersebut terletak pada pokok bahasan, penelitian ini secara khusus membahas mengenai urgensi dan prosedur pembentukan revisi Undang-Undang KPK.

\section{PERUMUSAN MASALAH}

Masalah yang dijadikan fokus pada penelitian adalah urgensi dan prosedur pembentukan revisi Undang-Undang KPK.

\section{METODE PENELITIAN}

Penelitian ini adalah penelitian hukum doktrinal yang bersifat normatif, ${ }^{14}$ yaitu menggunakan Perundang-undangan sebagai landasan dalam melakukan analisis terhadap masalah-masalah penelitian.

\section{PEMBAHASAN}

\section{Urgensi Revisi Terhadap UU KPK}

Hukum dalam arti undang-undang tidak pernah final karena akan selalu berubah sejalan dengan perubahan masyarakat dan sistem ketatanegaaran suatu bangsa. Namun perubahan suatu UndangUndang perlu diuraikan hal-hal apa yang menjadi urgensi sehingga perlu dilakukan perubahan. Halhal yang bersifat urgensi dapat diartikan sebagai "kegentingan yang memaksa". Sebagaimana telah ditafsirkan oleh Mahkamah Konstitusi dan dituangkan dalam "Putusan MK No 138/PUUVII/2009" yang pada pokoknya memberikan tiga indikator kegentingan yang memaksa yaitu, adanya kekosongan hukum, keadaanya yang mendesak, dan pembuatan UU melalui proses yang panjang sehingga perlu dikeluarkan Peraturan Pemerintah Pengganti Undang-Undang (Perpu). ${ }^{15}$ Pada hakikatnya halhal yang sifatnya urgensi atau kegentingan yang memaksa dapat dilihat dalam suatu dokumen ilmiah yang disebut Naskah Akademik yang merupakan hasil penelitian yang bisa dipertanggungjawabkan secara ilmiah.

\footnotetext{
${ }^{14}$ Peter Mahmud Marzuki. (2008). Pengantar Ilmu Hukum. Jakarta: Kencana, h. 23.

15 Putusan Mahkamah Konstitusi Republik Indonesia Nomor 138/PUU-VII/2009. Mahkamah Konstitusi, 8 Febuari 2018, h. 19.
}

Sebelum membahas mengenai urgensi revisi UU KPK, perlu dikemukakan bahwa, Politik hukum mempunyai konsekuensi logis, yaitu wewenang yang dimiliki legislator yang merupakan para elite politik, dalam membentuk peraturan perundang-undangan seringkali dijadikan sarana untuk memperoleh kepentingan politiknya dan partai politiknya bukan untuk kepentingan rakyat. ${ }^{16}$ Pembentukan peraturan perundang-undangan yang terburu-buru akan menghasilkan Undang-undang yang tidak memuaskan, karena pada umumnya didorong oleh kepentingan sesaat, tidak sistematis, kadang isinya tumpang tindih, dan pada umumnya tidak berumur panjang. ${ }^{17}$ Kedua landasan argumen mengenai politik hukum pembentukan peraturan perundang-undangan ini mengingatkan kita bahwa dibentuknya suatu aturan tidak bisa dilepaskan dari kepentingan politik, oleh para legislator (elite politik), dan pembentukan undang-undang yang dilakukan secara tiba-tiba mengindikasikan kepentingan politik tersebut.

Kembali pada persoalan urgensi dilakukannya revisi terhadap "Undang-undang KPK No. 30 Tahun 2003". Dalam Naskah Akademik RUU KPK" menyatakan UU KPK yang lama tidak lagi sesuai dengan perkembangan zaman, dinamika hukum serta sistem ketatanegaraan Republik Indonesia, sehingga perlu dilakukan perubahan terhadap UU KPK. Maka, saat ini UU KPK telah diubah menjadi UU No 19 Tahun 2019. Pada Naskah akademik RUU KPK $a$ qou juga dikatakan bahwa Praktik penegakan hukum pidana korupsi sering menghadapi permasalahan baik dari segi auturannya maupun dari segi substansi dan interpretasinya ${ }^{18}$ Artinya dalam naskah akademik ini menyatakan bahwa UU KPK No. 30 Tahun 2002, menimbulkan berbagai permasalahan hukum dalam pelaksanaannya.

Ketentuan mengenai wewenang dan penggunaan wewenang penyidikan oleh KPK dalam "UndangUndang 30 Tahun 2002", menyimpang dan

\footnotetext{
${ }^{16}$ Ferry Irawan Febriansyah. (2012). "Muatan Kepentingan Politik Penentu Kualitas Undang-Undang”. Jurnal Perspektif. 17(3), 184-190. DOI: http://dx.doi.org/10.30742/perspektif. v17i3.107.

${ }^{17}$ Sudikno Mertokusumo. (2014). Teori Hukum (Edisi Revisi), Yogyakarta: Cahaya Atma Pustaka, h. 29.

18 Naskah Akademik Rancangan Undang-Undang Republik Indonesia No. 19 Tahun 2019 tentang Perubahan Kedua atas Undang-Undang No. 30 Tahun 2002 tentang Komisi Pemberantasan Tindak Pidana Korupsi, h. 5.
} 
Madaskolay Viktoris Dahoklory dan Muh Isra Bil Ali,

Menyoal Urgensi dan Prosedur Pembentukan Revisi Undang-Undang Komisi Pemberantasan Korupsi

bertentangan dengan ketentuan umum hukum pidana sebagaimana diatur dalam KUHP. Sehingga ketentuan mengenai wewenang dan penggunaan wewenang penyidikan oleh KPK dalam UndangUndang 30 Tahun 2002, termasuk perbuatan yang melawan hukum. ${ }^{19}$ Sehingga karena bertentangan maka perlu untuk dilakukan perubahan aturan mengenai wewenang penyidikan oleh KPK tersebut. Pada bagian kesimpulan Naskah Akademik a quo, bahwa ditujukan agar terjadi sinkronisasi secara vertikal dan horizontal dalam rangka tegaknya asas persamaan di depan hukum, penyelenggaraan peradilan pidana yang adil, dan proses peradilan pidana yang non-diskriminatif.

Berdasarkan uraian dari Naskah Akademik di atas bisa dirangkum beberapa poin yang menjadikan revisi "Undang-Undang 30 Tahun 2002" di rasa urgent untuk dilakukan, adapun poin tersebut antara lain adalah pertama bahwa "Undang-Undang 30 Tahun 2002" sudah tidak sesuai lagi dengan perkembangan zaman, dinamika hukum serta sistem ketatanegaraan Republik Indonesia, kedua bahwa penegakan hukum terkait pemberantasan korupsi berdasarkan pada "Undang-Undang 30 Tahun 2002", sering menimbulkan berbagai permasalahan hukum, dan poin ketiga bahwa ketentuan mengenai wewenang penyidikan yang dilakukan oleh KPK, didasarkan pada "Undang-Undang 30 Tahun 2002", telah bertentangan dengan ketentuan umum hukum pidana, sehingga harus dilakukan revisi terhadap UU KPK yang lama.

\section{Prosedur Pembentukan UU yang Baik dan Benar Menurut Undang-Undang Nomor 15 Tahun 2019}

Pembentukan peraturan perundang-undangan dalam arti Pembentukan undang-undang berdasarkan UU No. 15 Tahun 2019 tentang Pembentukan Peraturan Perundang-undangan, harus memuat landasan filosofis, yuridis, dan sosiologis..$^{20}$ Ketiga landasan ini terdapat dalam sebuah naskah akademik yang bisa dipertanggungjawabkan secara ilmiah. Pada hakikatnya dalam suatu undang-undang terdapat konsideran menimbang dan mengingat. Kedua konsideran ini memiliki arti tersendiri bahwa dalam konsideran menimbang terkandung makna

\footnotetext{
19 ibid., h. 24.

${ }^{20}$ Putra Astomo. (2018). Ilmu Perundang-Undangan Teori dan Praktik di Indonesia. Depok: Rajawali Pers, h. 74-79.
}

filosofis, politis dan sosiologis yang menjelaskan mengapa undang-undang ini perlu direvisi, sedangkan konsideran mengingat terkandung makna yuridis. Oleh karena itu, ketiga landasan ini sangat diperlukan dalam pembentukan suatu UndangUndang, apabila ketiadaan salah satu landasan maka berakibat cacat hukum. "Menurut UUD NRI 1945, DPR memegang kekuasaan membentuk UndangUndang dengan persetujuan bersama Presiden. Seluruh RUU wajib dilakukan pembahasan antara DPR dan Presiden untuk mendapatkan kesepakatan. Bila RUU hasil kesepakatan tersebut tidak disahkan oleh presiden maka dalam waktu 30 (tiga puluh) hari, maka RUU itu sah dan harus diundangkan. Maka ini adalah bentuk UU dalam arti materiil dan bukan UU dalam arti formal. Karena UU dalam arti materiil cukup dengan adanya persetujuan bersama dalam paripurna maka RUU dapat dianggap telah menjadi UU, berbeda halnya dengan UU dalam arti formal yang mana melalui prosedur perencanaan sampai dengan pengundangan hingga diberi penomoran, tanggal, bulan, dan tahun. Konstitusi dalam arti UUD NRI 1945 dalam 22A mengatur bahwa pembentukan perundang-undangan akan diatur dalam UndangUndang. ${ }^{21}$ Sehingga dibentuklah UU Nomor 15 Tahun 2019 tentang Pembentukan Peraturan Perundang-undangan, menjadikan prinsip negara hukum, sebagai landasan dalam pembentukan setiap peraturan perundang-undangan.

Sebagai negara hukum, artinya segala aspek kehidupan bangsa Indonesia wajib tunduk pada hukum di Indonesia. ${ }^{22}$ Maka sekiranya, proses pembentukan UU harus melalui prosedur yang jelas dan tepat sebagaimana diatur oleh UU. 23 "Burkhardt Krems" sebagaimana dikutip oleh "Attamimi" menyatakan bahwa "pembentukan peraturan perundang-undangan meliputi kegiatan yang berhubungan dengan isi atau substansi peraturan, metode pembentukan, serta proses dan prosedur pembentukan peraturan. Setiap bagian kegiatan harus memenuhi persyaratanpersyaratannya tersendiri agar produk hukum dapat

\footnotetext{
${ }^{21}$ UUD NRI 1945.

22 Muntoha. (2009). "Demokrasi dan Negara Hukum". Jurnal Hukum Ius Quia Iustum. 3(16), 379-395. DOI: 10.20885/ iustum.vol16.iss3.art4

23 Daniel Samosir. (2015). "Faktor-faktor yang Menyebabkan Materi Muatan Undang-Undang Bertentangan dengan UUD 1945”. Jurnal Konstitusi. 12(4), 773-794. DOI: https://doi.org/10.31078/jk1246
} 
berlaku sebagaimana mestinya, baik secara yuridis, politis, maupun sosiologis". ${ }^{24}$ Menurut "UU No 15 Tahun 2019", Tahapan pembentukan UU yaitu perencanaan, penyusunan, pembahasan, pengesahan atau penetapan, dan pengundangan", berikut penjelasannya:

"Perencanaan dalam tahapan ini pada prinsipnya dilakukan suatu perencanaan pembentukan UU yang ditetapkan pada Prolegnas untuk jangka waktu lima tahun masa kerja DPR". "Penyusunan di tahapan ini setiap RUU yang berasal dari DPR atau Presiden harus Naskah Akademik yang memuat landasan filosofis, yuridis, dan sosiologis, serta alasan-alasan mengapa perlu dilakukan pembentukan undangundang". "Pembahasan dalam tahapan ini dilakukan melalui (2) dua tingkat pembicaraan. Pembicaraan tingkat I (satu) dalam rapat komisi, rapat gabungan komisi. Pembicaraan tingkat II (dua) dalam rapat paripurna". "Pengesahan dalam tahapan ini apabila telah dicapai persetujuan bersama antara DPR dan Presiden maka Pimpinan DPR menyampaikan RUU ke Presiden untuk pengesahan menjadi Undang-Undang, namun apabila Presiden tidak mengesahkan rancangan undang-undang hasil kesepakatan tersebut, maka dalam jangka waktu maksimal 30 (tiga puluh) hari, RUU tersebut sah menjadi UndangUndang dan harus diundangkan. "Pengundangan adalah proses terakhir menurut prosedur pembentukan peraturan perundang-undang, yaitu dengan menempatkan Undang-Undang yang telah disahkan dalam lembaran negara dan penjelasannya dimuat dalam tambahan lembaran negara agar setiap orang mengetahuinya". ${ }^{25}$

Kelima Prosedur ini merupakan suatu kesatuan yang tidak terpisahkan, maka setiap RUU yang datang dari usul inisiatif DPR maupun Presiden harus melalui prosedur-prosedur atau tahapan-tahapan tersebut.

\section{Prosedur Pembentukan Revisi UU KPK}

Apabila dicermati perubahan "UU KPK" sebagaimana telah diubah menjadi "UU No 19 Tahun 2019" tidak mengikuti salah satu prosedur atau

\footnotetext{
${ }^{24}$ Wahyu Nugroho. (2013). "Menyusun Undang-Undang yang Responsif dan Partisipatif Berdasarkan Cita Hukum Pancasila”. Jurnal Legislasi Indonesia. 10(3), 209.

${ }^{25}$ Undang-Undang Nomor 12 Tahun 2011.
}

tahapan yang dimaksud yaitu tahapan "perencanaan" atau dengan kata lain perubahan "UU KPK" tidak dimuat dalam prolegnas jangka waktu lima tahun (2014-2019), sedangkan "Pasal 45 ayat (1) UU No. 15 Tahun 2019 menentukan peryaratan RUU wajib berdasarkan Prolegnas". Bahkan "UU No. 15 Tahun 2019" mengamanatkan agar seharusnya melibatkan partisipasi masyarakat, LSM, KPK sebagai lembaga negara terkait namun hal itu justru diluar ekspektasi. Maka, seyogianya Revisi UU KPK harus dianggap cacat prosedur (an-prosedural) dan demi kepastian hukum UU KPK harus dibatalkan. Tidak hanya demikian, bahkan perubahan UU KPK juga terdapat keanehan-keanehan dalam prosesnya pembentukannya dimana proses pembahasan dan pengesahannya begitu cepat dilakukan oleh DPR. Sementara itu, terdapat antrean RUU Pertanahan, RUU Penghapusan Kekerasan Seksual, dan RUU lainnya yang sebetulnya telah dimuat terlebih dahulu dalam prolegnas tetapi justru tidak disahkan menjadi UU oleh DPR. Hal ini, mengindikasikan masalah dalam perubahan "UU KPK".

Perspektif Politik Hukum seperti halnya yang dijelaskan oleh Mahfud MD, dalam bukunya "Politik Hukum di Indonesia" sebagaimana menggunakan konsep atau istilah konfigurasi politik yang demokratis dan otoriter, serta karakter responsif dari suatu produk hukum dan konservatif. Jika konfigurasi politik yang demokratis maka nantinya membuat suatu produk hukum yang responsif, sebaliknya apabila apabila kondisi politik yang otoriter akan menghasilkan produk hukum yang konservatif. Contoh Undang-Undang Pokok Agraria (UUPA) adalah produk hukum responsif, karena dapat menjawab masalah pertanahan hingga masa reformasi. Sebaliknya UU Pemilu adalah produk hukum yang konservatif karena dibentuk berdasarkan kepentingan elite politik sehingga selalu dilakukan perubahan. ${ }^{26}$

Maka, yang menjadi pertanyaannya adalah apakah revisi UU KPK termasuk kondisi politik otoriter sehingga mengasilkan hukum yang konservatif ataukah konfigurasi politik yang demokratis sehingga menghasilkan hukum yang responsif. Pertanyaan itu, sebetulnya dapat dilihat dari dua aspek, yaitu aspek substansi UU KPK

${ }^{26}$ Mahfud MD, Politik Hukum di Indonesia, (Cet ke-V: Rajawali PERS, 2012). Hlm. 20,21,22 
dan aspek prosedur pembentukan UU KPK itu sendiri. Apabila, dilihat dari aspek prosedural pembentukan UU KPK terdapat kecacatan prosedur/ yuridis maupun substansi materi muatan UU KPK berpontensi melemahkan atau memperlambat tugas dan wewenang KPK di kemudian hari, maka dapat dikatakan bahwa ini adalah konfigurasi politik yang otoriter sehingga melahirkan produk hukum yang berkarakter konservatif. ${ }^{27}$

Saat ini UU KPK yang baru sedang di uji konstitusionalitasnya oleh Mahkamah Konstitusi (MK). MK berwenang untuk "menguji UU terhadap UUD. "28 Putusan Mahkamah Konstitusi bersifat final and binding artinya sejak Putusan Mahkamah Konstitusi diucapkan dalam persidangan yang terbuka untuk umum, maka secara otomatis berlaku untuk semua orang (erga omnes), dan tidak adalagi upaya hukum yang bisa diambil untuk membatalkan putusan tersebut. ${ }^{29}$

Terkait dengan kewenangan Mahkamah Konstitusi untuk melakukan pengujian formil dalam kaitannya dengan pengujian "UU No 19 Tahun 2019", Mahkamah Konstitusi harus mampu berperan aktif dalam menjaga dan menegakkan konstitusi. Selain itu, Mahkamah juga dituntut untuk tidak hanya menilai dari perspektif Hukum Tata Negara saja, melainkan harus memperhatikan dan menilai secara komprehensif dinamika politik legislasi UU KPK yang dilaksanakan oleh DPR serta fakta-fakta politik dan keanehan-keanehan apa saja yang terjadi dalam setiap tahapan revisi "UU KPK" tersebut. Seperti yang telah dijelas dalam subbab sebelumnya bahwa dalam prosedur revisi UU KPK tidak mengikuti prosedur dan tahapantahapan yang telah diatur dalam "UU No. 15 Tahun 2019 tentang Pembentukan Peraturan Perundangundangan". Antara lain tahapan perencanaan yang seyogianya suatu Undang-Undang harus dimuat dalam Prolegnas yakni program kerja DPR selama jangka waktu lima (5) Tahun, sebelum nantinya akan

27 Mahfud MD. (2006). Membangun Politik Hukum Penegakkan Konstitusi. Cet Pertama. Jakarta: Pustaka LP3ES Indonesia, h. 32.

${ }^{28}$ Antoni Putra. (2018) "Dualisme Pengujian Peraturan Perundang-Undangan”. Jurnal Legislasi Indonesia. 15(2), 69-79.

${ }^{29}$ Mohammad Agus Maulidi. (2017). "Problematika Hukum Implementasi Putusan Final dan Mengikat Mahkamah Konstitusi Perspektif Negara Hukum”. Jurnal Ius Quia Iustum. 24(4), 535557. DOI: https://doi.org/10.20885/iustum.vol24.iss4.art2 dilanjutkan ke tahapan penyusunan, pembahasan, pengesahan atau penetapan, dan pengundangan hingga proses sosialisasi/penyebarluasan. Namun pada kenyataannya UU KPK sebelumnya tidak dimuat dalam Prolegnas bahkan dalam tahapan pembahasan dan pengambilan keputusan (sidang Paripurna) anggota DPR tidak memenuhi kuorum sebagaimana yang telah diatur dalam Peraturan DPR tentang Tata terbit.

Berdasarkan pemaparan mengenai prosedur pembentukan revisi "UU KPK No. 19 Tahun 2019 dan proses Judisial Review yang sedang diajukan, bisa ditarik kesimpulan bahwa prosedur pembentukan revisi UU KPK, telah cacat prosedur sebagaimana diatur dalam UU No. 15 Tahun 2019 tentang Pembentukan Peraturan Perundang-Undangan”, sehingga juga bertentangan dengan UUD NRI tahun 1945. Itu sebabnya, revisi "UU KPK" dikhawatirkan tidak hanya berpotensi merugikan KPK tetapi seluruh masyarakat Indonesia yang giat melawan korupsi, maka demi hukum dan kepentingan masyarakat UU KPK yang baru harus dibatalkan oleh Mahkamah Konstitusi dan dinyatakan bertentangan dengan konstitusi dan tidak memiliki kekuatan hukum mengikat.

\section{PENUTUP \\ Kesimpulan}

Berdasarkan hasil penelitian bisa disimpulkan bahwa urgensi dilakukannya revisi "Undang-Undang No. 30 Tahun 2002, tentang KPK adalah pertama bahwa "Undang-Undang 30 tahun 2002" sudah tidak sesuai lagi dengan perkembangan zaman, dinamika hukum serta sistem ketatanegaraan Republik Indonesia, kedua bahwa penegakan hukum terkait pemberantasan Korupsi berdasarkan pada "Undangundang 30 tahun 2002", sering menimbulkan berbagai permasalahan hukum, dan poin ketiga bahwa ketentuan mengenai wewenang penyidikan yang dilakukan oleh KPK, didasarkan pada "UndangUndang 30 tahun 2002", telah bertentangan dengan ketentuan umum hukum pidana, sehingga harus dilakukan revisi terhadap UU KPK yang lama. Prosedur Pembentukan Undang-Undang dalam hal ini Revisi UU KPK tidak melalui prosedur atau tahapantahapan sebagaimana diatur dalam "UU No. 15 Tahun 2019" antara lain, tahapan perencanaan, penyusunan, pembahasan, pengesahan atau penetapan, dan 
pengundangan sehingga mengakibatkan terdapat banyak sekali kesalahan-kesalahan dan kecacatan yuridis dalam revisi UU KPK.

\section{Rekomendasi}

Presiden selaku Kepala Negara dan Kepala Pemerintahan perlu menetapkan PERPU sebagai upaya untuk mengintegrasikan kepentingankepentingan politik serta dinamika hukum nasional. Dilain sisi, apabila PERPU tidak dapat menjadi solusi penyelesaian masalah, maka Mahkamah Konstitusi adalah pintu keadilan terakhir yang dicari oleh masyarakat, melalui mekanisme Jucidial Review. Jika hasil judisial Review ditolak untuk seluruhnya, maka perlu adanya reformasi hukum dan konstitusi untuk memperkuat kedudukan, tugas, serta wewenang KPK dengan cara meng-amandemen ke-lima "UndangUndang Dasar NRI 1945”. Bahkan dalam setiap agenda Pembentukan Undang-Undang dalam hal ini Revisi UU KPK wajib melibatkan partisipasi rakyat secara aktif agar dapat melahirkan produk hukum yang berkarakter responsif.

\section{DAFTAR PUSTAKA}

\section{Peraturan Perundangan-Undangan:}

Undang-Undang Dasar Negara Republik Indonesia Tahun 1945.

Undang-Undang Nomor 31 Tahun 1999 tentang Pemberantasan Tindak Pidana Korupsi.

Undang-Undang Nomor 30 Tahun 2002 tentang Komisi Pemberantasan Korupsi.

Undang-Undang Nomor 12 Tahun 2011 tentang Pembentukan Peraturan Perundang-Undangan.

Peraturan Mahkamah Konstitusi Republik Indonesia Nomor 6 Tahun 2005 tentang Pedoman Beracara dalam Pengujian Undang-Undang.

Naskah Akademik Rancangan Undang-Undang Komisi Pemberantasan Korupsi.

Naskah Akademik Rancangan Undang-Undang Republik Indonesia No. 19, Tahun 2019 tentang Perubahan Kedua atas Undang-Undang No. 30 Tahun 2002 Tentang Komisi Pemberantasan Tindak Pidana Korupsi.

\section{Putusan:}

Putusan Mahkamah Konstitusi Republik Indonesia

Nomor 138/PUU-VII/2009. Mahkamah Konstitusi, 8 Febuari 2018.

\section{Buku:}

Deni Styawati. (2008). KPK Pemburu Koruptor (Cet 1). Yogyakarta: Pustakan Timur.

Mahfud MD. (2006). Membangun Politik Hukum Penegakkan Konstitusi. Cet Pertama. Jakarta: Pustaka LP3ES Indonesia. (2012). Politik Hukum di Indonesia, Cet ke-V. Jakarta: Rajawali PERS.

Peter Mahmud Marzuki. (2008). Pengantar Ilmu Hukum. Jakarta: Kencana.

Putra Astomo. (2018). Ilmu Perundang-Undangan Teori dan Praktik di Indonesia. Depok: Rajawali Pers.

Rimawan Pradiptyo, Teguh Dartanto, Sonny Priyarsono, Maman Setiawan, Gumilang Aryo, Sahadewo, Putu Sanjiwacika Wibisana. (2019). "Naskah Akademik, Menghapus Pulau Berintegritas Atau Membangun Kepulauan Berintegritas? Rekomendari Ekonom Terhadap Pelemahan Penindakan dan Pencegahan Korupsi”. Departemen Ilmu Ekonomi (UI, IPB, UNPAD, UGM).

Sudikno Mertokusumo. (2014). Teori Hukum (Edisi Revisi). Yogyakarta: Cahaya Atma Pustaka.

\section{Jurnal:}

Antoni Putra. (2018) "Dualisme Pengujian Peraturan Perundang-Undangan”. Jurnal Legislasi Indonesia. 15(2), 69-79.

Dalinama Telaumbanua. (2020) "Restriktif Status Dewan Pengawas KPK”. Jurnal Education and Development. 8(1), 258-258.

Daniel Samosir. (2015). "Faktor-faktor yang Menyebabkan Materi Muatan Undang-Undang Bertentangan dengan UUD 1945". Jurnal Konstitusi. 12(4), 773-794. DOI: https://doi. org/10.31078/jk1246

Edita Elda. (2019). “Arah Kebijakan Pemberantasan Tindak Pidana Korupsi di Indonesia:Kajian Pasca Perubahan Undang-Undang Komisi Pemberantasan Korupsi”. Lex LATA. 1(2), 153170.

F. Fazzan. (2015). "Korupsi di Indonesia dalam Perspektif Hukum Pidana Islam.” Jurnal Ilmiah Islam Futura. 14(2), 146-165. DOI: http://dx.doi. org/10.22373/jiif.v14i2.327.

Ferry Irawan Febriansyah. (2012). "Muatan Kepentingan Politik Penentu Kualitas Undang- 
Undang”. Jurnal Perspektif. 17(3), 184-190. DOI: http://dx.doi.org/10.30742/perspektif. v17i3.107.

Ibu Srinita. (2016). "Strategi Menihilkan Korupsi di Sektor Pendidikan dan Kesehatan". Jurnal Kajian Politik dan Masalah Pembangunan. 12(2), 1891-1902.

Mohammad Agus Maulidi. (2017). "Problematika Hukum Implementasi Putusan Final dan Mengikat Mahkamah Konstitusi Perspektif Negara Hukum". Jurnal Ius Quia Iustum. 24(4), 535-557. DOI: https://doi.org/10.20885/iustum. vol24.iss4.art2

Muntoha. (2009). "Demokrasi dan Negara Hukum". Jurnal Hukum Ius Quia Iustum. 3(16), 379-395. DOI: 10.20885/iustum.vol16.iss3.art4

Novian Ardynata Setya Pradana, Arif Subekti, dan Cahyo Harjo Prakoso. (2019). "Kewenangan Lembaga Hukum Dalam Menentukan Besaran Kerugian dan Pengembalian Keuangan Negara Hasil Tindak Pidana Korupsi”. Jurnal Perspektif, 24(3), 137-146, doi. http://dx.doi.org/10.30742/ perspektif.v24i3.719

Totok Sugiarto. (2013). "Peranan Komisi Pemberantasan Korupsi (KPK) dalam Pemberantasan Tindak Pidana Korupsi di Indonesia”. Jurnal Cakrawala Hukum. 18(1), 188-196.

Wahyu Nugroho. (2013). "Menyusun UndangUndang yang Responsif dan Partisipatif Berdasarkan Cita Hukum Pancasila”. Jurnal Legislasi Indonesia. 10(3), 209.
Yokotani dan Ndaru Satrio. (2019). "Mekanisme Seleksi Dewan Pengawas Komisi Pemberantasan Korupsi Dalam Perspektif Cita Hukum Pancasila”. Jurnal Hukum Progresif. 13(2), 115133. DOI: https://doi.org/10.33019/progresif. v13i2.1452.

\section{Website:}

Website Komisi Pemberantasan Korupsi, https:// www.kpk.go.id/id/statistik/penindakan, diakses pada 27 Maret 2020.

Hussein Abri, Editor: Ninis Chairunnisa. (Jumat, 2 Februari 2018). "Berikut Ini 10 Rekomendasi Pansus Hak Angket untuk KPK", (https:// nasional.tempo.co/read/1056595/berikut-ini10-rekomendasi-pansus-hak-angket-untuk-kpk, diakses pada 29 Maret 2020.

\section{Makalah:}

KASUM. (2010). "Korupsi adalah Kejahatan HAM". Makalah disampaikan pada acara Munir Memorial Lecture (MML) IV Samanta Krida Conventional Hall Universitas Brawijaya, 29 September 2010, h. 2.

Naskah Akademik Rancangan Undang-Undang Republik Indonesia No. 19 Tahun 2019 tentang Perubahan Kedua atas Undang-Undang No. 30 Tahun 2002 tentang Komisi Pemberantasan Tindak Pidana Korupsi, h. 5. 